\title{
Die Christen en die owerheid volgens Romeine 13:1-7
}

\author{
GMM Pelser
}

\section{Abstract}

The Christian and the ruling authorities according to Romans 13:1-7

In this article the question is posed as to the appropriate understanding and applicability of Romans 13:1-7 in modern times and modern political situations, especially in the light of world wide revolutionary tendencies and activities. First the most crucial exegetical questions inherent in and attached to the passage in the history of exegesis are examined and commented on. The conclusion arrived at, is that although the passage as a self-contained unit stands somewhat loose from its paraenetical context and has its parallels in Jewish-Hellenistic thought, there is no reason to minimise the thrust of its admonition to subjection to ruling authorities. This cannot be done either on the grounds that the passage is non-Pauline or on the grounds of metaphysical, historico-political or eschatological considerations. Regarding the understanding and applicability of the passage in our present situation, the conclusion is that the Christian at least should always adhere to the main purport of the passage, but not necessarily unqualified. Because the passage stands hermeneutically in a dialectical relationship to every new situation, it should be treated in a responsible way in such new situation without, however, either letting the situation prescribe the exegesis or letting the passage enforce itself as dogma upon the situation.

Dit is te begrype dat hierdie perikoop in die geskiedenis van die eksegese ' $n$ sentrale rol gespeel het wanneer daar ook al eksegetiesteologies besin moes word oor die plek, gesag, verantwoordelikheid en funksie van die owerheid, maar dan veral ook oor die vraag hoe die Christen hom teenoor die owerheid moet gedra (kyk Wilckens 1982: 43-66). Die perikoop het, soos bekend, veral in die brandpunt van die teologiese diskussie gestaan wanneer daar by die onderdane van een of ander owerheid ernstige ontevredenheid met die owerheid bestaan het of wanneer daar by hulle selfs opstand of revolusie gedreig het. Dit is tans ook bykans wêreldwyd die geval in die revolusionêre tye waarin ons lewe, en nie minder nie ook in Suid-Afrika, dat hierdie perikoop om ernstige besinning vra. Dit is vir almal duidelik dat die perikoop steeds die spreekwoordelike hoë hekkie bly waaroor daar in die dis- 
kussie eksegeties gekom moet word, wat ook al die vooronderstellings waarmee dit benader word.

Die rede waarom hierdie perikoop so in die brandpunt staan, is voor-die-hand-liggend. Hoewel die gedagte van of die eis vir onderwerping aan die owerheid naamlik nie slegs hier in die Nuwe Testament voorkom nie (kyk ook Tit 3:1, 1 Pet 2:13 en vgl Mark 12:13-17 par; 1 Tim 2:2), is dit slegs hier dat met betrekking tot die owerheid gesê word dat daar geen gesag (exousia) is wat nie van God kom nie (vgl egter Joh 19:11), en dat die owerheid wat daar is, daar is deur die beskikking van God (tetagmenai eisin, vs 1 ; vgl verder die uiteensetting van ooreenkomste en verskille by Riekkinen 1980: $69 \mathrm{v}$ ). Dit is dan ook in lyn hiermee dat die verdere stelling gemaak word dat wie hom teen (die owerheids-) gesag verset, in opstand kom teen die ordening (diatag $\bar{e}$ ) van God (vs 2), en dat die (owerheids-) gesag 'n dienaar (diákonos, vs 4; leitourgós, vs 6) van God is. Basies word daar dus gewoon en ongekwalifiseerd in hierdie perikoop gestel dat die owerheid ' $n$ instelling van God en ' $n$ dienaar van God is en dat ' $n$ mens jou aan die owerheid moet onderwerp en hom gehoorsaam moet wees, anders verset jy jou in feite teen God.

'n Benadering soos hierdie lewer natuurlik geen probleme op wanneer daar algemene of selfs redelike tevredenheid en instemming met die doen en late van die owerheid bestaan nie. Dit het egter telkens 'n probleem geword wanneer onderdane of 'n deel van hulle, nie aangename ervarings van ' $n$ bepaalde owerheid gehad het nie. Dit is dan wanneer daar allerlei vrae rondom hierdie perikoop na vore kom.

\section{EKSEGETIESE PROBLEEMVRAE RONDOM DIE PERIKOOP}

Gaan kyk 'n mens na die geskiedenis van die eksegese van hierdie perikoop en veral na die hantering daarvan gedurende die laaste paar dekades, dan is dit ' $n$ taamlik verwarrende en uiteenlopende prentjie wat hom voor jou ontplooi. Dit word gou duidelik dat daar verskeie probleemvrae rondom die teks bestaan waarmee die eksegese gekonfronteer is en word. Die belangrikste kwessies is die volgende (vgl Reese 1973: 323): Pas die perikoop in sy konteks? En indien nie, is dit tog wel Paulinies of is dit 'n nie-Pauliniese interpolasie? Is dit Christologies gefundeer of nie? Is die perikoop se inhoud of strekking tradisioneel Joods of Hellenisties? Is dit geskrywe met 'n konkrete historiese situasie in gedagte en daarom situasiebepaald? Waarna verwys exou- 
siai? Is die oproep tot onderworpenheid werklik so ongekwalifiseerd bedoel as wat dit op die oppervlak voorkom?

Dit is duidelik dat daar by 'n ondersoek na die betekenis en implikasie van hierdie perikoop onvermydelik aan bogenoem de probleemvrae aandag gegee sal moet word, aangesien die antwoord wat op elkeen van hulle gegee word, in ' $n$ mindere of meerdere mate bepalend sal wees vir die uiteindelike eksegetiese resultaat. In wat hieronder volg, sal hierdie vrae dan ook afsonderlik aan die orde gestel word in 'n poging om tot groter klaarheid oor die teks te kom. Daar sal egter nie 'n detail-eksegese van die perikoop onderneem word nie, aangesien ek my slegs wil bepaal by wat die kern van die probleem blyk te wees met betrekking tot die perikoop se uitsprake oor die verhouding onderdaan-owerheid.

\subsection{Pas die perikoop in sy konteks?}

Dit verg nie veel insig om raak te sien dat hierdie perikoop 'n afgeronde en selfstandige argumentasie is nie. Dit is egter juis hierdie feit wat die vraag laat ontstaan na die verhouding daarvan met die omliggende konteks (Wilckens 1982: 30). Verskeie eksegete is van mening dat dit so selfstandig in die konteks staan dat dit as 't ware as ' $n$ invoeging beskou kan word. So praat Michel (1963: 312) byvoorbeeld daarvan as 'n 'selbständige Einlage' (kyk oor Ridderbos 1959: 287; Conzelmann \& Lindemann 1980: 229) en Käsemann (1974: 337) as 'n 'selbständiger Block' en 'n 'Fremdkörper' in die Pauliniese paranese, hoewel nie een van die twee ontken dat dit van Paulus is nie. Michel grond sy bewering hoofsaaklik daarop dat 12:21 sy direkte voortsetting by 13:8 het en dat die paranese oor die verhouding tussen medegelowiges (mens-medemens) wat met 12:9 begin en in 13:8 voortgesit word, derhalwe onderbreek word deur hierdie perikoop waarin in onderskeid daarmee gehandel word oor die verhouding onderdaanowerheid (vgl ook nog Kuss 1963: 247).

Verdere sake waarop gewys word as argument dat die perikoop los van sy konteks staan, is dat die styl, inhoud en wyse van argumentasie van dié van die konteks verskil, dat die eskatologiese perspektief soos uitgedruk in 12:2 en 13:11-14 hier ontbreek en so ook die liefdetema wat só 'n sentrale tema in 12:9-21 en $14: 8-10$ is, en dat die karakter van die perikoop nie Christelik is nie (kyk Wilckens 1982: 30; Käsemann 1974: 337 en vgl Riekkinen 1980: 44; Parrott 1980: 179 vv). 


\subsection{Is die perikoop 'n nie-Pauliniese interpolasie?}

In aansluiting by hierdie argumente oor die kontekslosheid van die perikoop, het 'n paar eksegete nog verder gegaan en die oortuiging uitgespreek dat dit in werklikheid ' $n$ nie-Pauliniese interpolasie is (so Eggenberger, Barnikol, Kallas, O'Neill - kyk Riekkinen 1980: 8 vv vir 'n oorsig; Schmithals 1975: 196). Daar word byvoorbeeld nog verder aangevoer dat die styl volkome nie-Paulinies is, dat die strekking van die perikoop die apokaliptiese karakter van die vroegste Christendom weerspreek, dat dit nie vóór 180 n C gesiteer is nie, dat exousía nie deur Paulus vir 'n aardse owerheid gebruik word nie, maar slegs vir demoniese magte en dat die vroegste Christene teen hierdie tyd eerder negatief teenoor die staat moes gestaan het.

Hoewel daar, soos reeds in afdeling 1.1 hierbo aangedui, heelwat eksegete is wat vry ernstige vrae het oor die perikoop se plek in die konteks, kon die interpolasie-hipotese nog nie noemenswaardige steun vind nie. Daar blyk ook nie werklik deurslaggewende redes te wees op grond waarvan daar so 'n drastiese stap gedoen moet word as om die gedeelte as nie-Paulinies te beskou nie. Ook nie alle eksegete is van mening dat die perikoop inderdaad uit pas met sy konteks is nie. Daar word byvoorbeeld op gewys dat terwyl 12:3-16a handel oor die verhouding tussen gelowiges onderling, daar in $12: 16 \mathrm{~b} v \mathrm{vv}$ gehandel word oor die houding wat die gelowige teenoor die nie-gelowige moet inneem. In die lig hiervan word 13:1 vv dan beskou as ' $n$ natuurlike voortsetting van $12: 16 \mathrm{~b}-21$. Ook word daar gewys op konteksverwantskap deur middel van woorde of begrippe. So byvoorbeeld tò agathón en tò kakón in $12: 2,9,17,21$ en in 13:3,4; ekdikēsis in 12:19 en ékdikos in 13:4; timē in 12:10 en 13:7; orge in 12:19 en 13:4,5; ofeilas in 13:7 en ofellete in 13:8; kakòn poieîn in 13:4 en kakòn ouk ergázesthai in 13:10 (vir ook nog ander argumente in hierdie verband kyk Barrett 1977: 144; Schlier 1958: 7; 1979: 386 v; Borg 1973: 214 v; Friedrich, Pöhlmann \& Stuhlmacher 1976: 146 vv; Riekkinen 1980: 45 vv; Parrott 1980: 182 vv; Hultgren 1976: 264; Schrage 1982: 227).

Hoewel dit wil voorkom of die opinies oor nie-kontekstualiteit en kontekstualiteit onderskeidelik min of meer balanseer, is dit tog so dat die meeste eksegete, waaronder selfs sommige van dié wat dit nie volkome los van die konteks wil sien nie, hierdie perikoop as 'n selfstandige eenheid interpreteer (vgl Reese 1973: 324). Die saak word miskien die beste opgesom deur Wilckens wat, hoewel hy self op 'n aantal kontekstuele verbindings wys, die volgende stelling maak: 'Nun 
fält jedoch die Mahnung zur Unterordnung unter die Gewalten aus diesem Kontext heraus. Das findet seine Erklärung in der Tat darin, dass es ein Topos gemein-urchristlicher Verhaltensregeln ist, den Paulus in 13, $1 \mathrm{ff}$ ausführt' (Wilckens 1982: 31).

Terwyl ons, soos reeds hierbo gestel, geen afdoende bewys het dat die perikoop nie-Paulinies is nie, blyk dit eweneens nie dat dit so in die konteks verweef is dat daar vanuit die konteks eksegeties veel lig gewerp word as hulp by die eksegese nie. Die perikoop staan inderdaad tot op groot hoogte indien nie volledig nie, selfstandig. Die meeste wat waarskynlik gesê kan word, is dat dit wel gesien moet word as deel van die paranetiese blok in die brief. Dit behoort ook nie as vreemd beskou te word dat daar as deel van so 'n paranetiese blok, 'n gedeelte opgeneem is waarin gehandel word oor die ingesteldheid wat die gelowige teenoor die owerheid moet hê nie. Solank as die gelowige nog in hierdie wêreld lewe en deel van hierdie werklikheid is, bly sy verhouding met die owerheid van die dag vir hom 'n eksistensiële saak wat nie geïgnoreer kan word nie.

\subsection{Is die perikoop Christologies gefundeer of nie?}

Een van die ernstige probleme wat deur 'n aantal eksegete met die perikoop ondervind word, is na hulle mening die totale afwesigheid van ' $n$ Christologiese fundering daarvan (vgl Reese 1973: 326 vv). Michel merk in hierdie verband op: 'Man wird darauf heinweisen müssen, dass jede christliche Einstellung in dieser Paränese fehlt ...' (Michel 1963: 313; kyk ook Bornkamm 1969: 216). Indien dit nie as tipies Christelik beskou sou kon word nie, laat dit natuurlik die vraag ontstaan of die eise wat daarin gestel word, wel 'n noemenswaardige en verpligtende rol moet speel in die Christen se visie op die owerheid.

Ons moet toegee dat daar as sodanig in die perikoop self geen eksplisiete Christologiese begronding aanwesig is nie, maar dit geld natuurlik ook vir die meeste ander etiese uitsprake in die Nuwe Testament. Dit kan as algemeen aanvaar beskou word dat daar wat die etiek van die Nuwe Testament betref, min is wat nie ò uit die Jodedom òf uit die Hellenistiese omgewing van die Nuwe-Testamentiese tydvak oorgeneem is nie (vgl Wendland 1970: 3; Schrage 1982: 16). Die erkenning van hierdie feit impliseer egter hoegenaamd nie dat die etiek van die Nuwe Testament daarmee eensklaps tot ' $n$ nie-Christelike etiek verklaar word nie. Wat ook al die herkoms van die etiek van die Nuwe Testament, feit is dat minstens in die breë gesien, die Christusgebeure 
hierdie etiek kwalifiseer. Dit beteken aan die ander kant egter ook weer nie dat alle etiese uitsprake in die Nuwe Testament sonder meer op dieselfde vlak onder een noemer geplaas kan word nie, of dat daar nie selfs bepaalde teenstrydighede te bespeur is nie.

Hieruit volg dat indien Romeine 13:1-7 nie na 'n spesifiek Christelike tradisie teruggevoer kan word nie, dit nie per se daarvan 'n nieChristelike etiese voorskrif maak nie. Om hierdie rede word in Christelike kring steeds daarmee erns gemaak, al word deur baie eksegete aanvaar dat dit na 'n nie-Christelike tradisie teruggevoer moet word. Wat egter nie meer betwyfel word nie, is dat ons hier met ' $n$ voorPauliniese tradisie te make het. 'Das "dass" der Traditionsverwendung wird nicht mehr diskutiert ...' (Riekkinen 1980: 95). Die vraag wat oorbly, is slegs dié na die oorsprong van hierdie tradisie.

\subsection{Watter tradisie lê ten grondslag aan die perikoop?}

Soos seker te verwag is, loop die menings oor hierdie vraag drasties uiteen. Dit wissel tussen Christelik (Neugebauer 1962: $165 \mathrm{v}$; e a), Joods-Christelik (Dibelius 1956: 182 vv), Hellenisties-Romeins (Parrott 1980: 173, 175; e a), Ou-Testamenties-Joods (Althaus 1970: 132; Wilckens 1982: 33); Joodse wysheid (Michel 1962: $313 \mathrm{v}$ ) en HellenistiesJoods (Käsemann 1974: 339). Die uiteenlopendheid van die antwoorde wat op hierdie vraag gegee word, is op sigself aanduiding van 'n gebrek aan deurslaggewende bewysmateriaal om enigeen van hierdie opinies onaanvegbaar te begunstig. Lê die oplossing dalk in ' $n$ kombinasie van meer as een of van al hierdie denkrigtings? Ons het 'n illustrasie van so 'n kombinasie by Friedrich et al wanneer die stelling: 'Röm 13, 1-4.6 nehmen also bis in Einzelheiten hinein die Sprache und Vorstellungswelt der hellenistisch-römischen Zeit auf', opgevolg word met: 'Neben der hellenistisch-römischen Verwaltungsprache sind aber die in den Text eingegangenen synagogalen und alttestamentlichen Überlieferungen nicht zu übersehen' (Friedrich et al 1976: 136 en 145 onderskeidelik).

'n Finale antwoord op hierdie vraag is dus nog uitstaade en sal waarskynlik nooit gegee kan word nie. Dit blyk ook dat nie alle literatuur uit Joodse of Hellenistiese kringe altyd eenstemmig was oor die vraag na die verhouding owerheid en onderdaan nie. ' $n$ Direkte aanhaling uit parallelle materiaal is Romeine 13:1-7 klaarblyklik nie (kyk Friedrich et al 1976: 147). Die meeste wat met redelike veiligheid op hierdie stadium gesê kan word, is dat daar in die perikoop elemente 
opgeneem is wat uit verskillende oorde kom en wat in 'n kring of kringe in die vroegste kerk ' $n$ bepaalde vorm aangeneem het. Deur wie dit gedoen is en hoe dit plaasgevind het, weet ons nie (kyk Riekkinen 1980: 95). Dat Paulus ook nog sy eie stempel daarop afgedruk het, kan seker nie ontken word nie. Wilckens (1982: 31) wys naamlik daarop dat daar in die perikoop ' $n$ hele aantal tipies Pauliniese woorde voorkom. Friedrich et al (1976: 147) voeg nog meer by en huldig die mening dat vers 5 wat deur Bultmann as 'n eksegetiese glosse beskou word, juis tipies Paulinies is. Hoe dit ook al sy, die feit dat die perikoop deel uitmaak van die paranese van die Romeinebrief, is reeds genoeg aanduiding daarvan dat Paulus hom vereenselwig het met die motiewe wat daarin vervat is.

\subsection{Is die perikoop situasiebepaald?}

Die wyse waarop die perikoop benader behoort te word, hang vir baie ook af van die vraag of Paulus hiermee 'n konkrete historiese situasie by die lesers in gedagte gehad het. Indien wel, laat dit natuurlik weer die vraag na vore kom of die uitsprake in die perikoop dan nie so situasiebepaald is dat dit slegs op daardie situasie van toepassing was en dus nie algemeen en vir alle tye geld nie. Dit blyk dat die meerderheid hedendaagse eksegete vermoed dat daar wel 'n bepaalde konkrete situasie as aanleiding veronderstel moet word. Wat hierdie situasie was, laat egter ook weer die menings uiteengaan. Sommige dink aan 'n waarskuwing teen meelopery met Joodse selotisme of belastingprotesbewegings (Borg 1973: $214 \mathrm{vv}$ ). In 'n sekere sin verwant hieraan is die gedagte dat Paulus die gelowiges in Rome wou waarsku om nie die belastingplig wat rondom $55 \mathrm{n} \mathrm{C}$ nog swaar op hulle gedruk het, te weier nie. In samehang hiermee word vers 6 en 7 dan ook nie gesien as maar slegs 'n opsommende afsluiting van die perikoop nie, maar as konkrete aanwysings met die oog op die situasie (Friedrich et al 1976: $153 \mathrm{vv}$; Wilckens 1982: 34). Máchairan foreîn word voorts geïnterpreteer as nie verwysend na die ius gladii van die Romeinse owerheid nie, maar na die gesag waarmee staats- of polisiebeamptes die betaling van belasting kon afdwing (Friedrich et al 1976: $140 \mathrm{vv}$ ). Ander vermoed die bekamping van religieuse entoesiasme wat gespruit het uit ' $n$ entoesiastiese vryheidsbewustheid (so bv Käsemann 1974: 341; vgl ook Nygren 1965: 303 v; Reese 1973: 329; Schlier 1979: 393). Hiervolgens moes die lesers dan gewaarsku word teen 'n beskouing dat alle aardse dinge vir die verlostes belangeloos is, ' $n$ gesindheid wat kon lei tot die min- 
agting van die aardse owerhede. Bornkamm (1969: 219) sien in die feit dat die perikoop in geen ander Paulusbrief 'n parallel het nie, grond vir die vermoede dat die lesers gevaar geloop het om hulle demonstratief van die owerheid te distansieer en hulle plig te versuim.

Van ' $n$ ietwat ander aard is die verklarings wat die aanleiding eerder by Paulus self soek as by die lesers se historiese omstandighede of politieke ingesteldheid. So word die mening gehuldig dat Paulus se gunstige evaluering van die owerheid toegeskryf moet word aan goeie ervarings wat hy self van die Romeinse owerheid gehad het of aan die feit dat die Christene op hierdie stadium nog nie vervolg is nie. Die implikasie is dus dat hy anders sou geoordeel het as daar reeds ' $n$ Christenvervolging ingetree het (kyk Riekkinen 1980: $98 \mathrm{v}$ vir ' $n$ bespreking hiervan en vgl onder andere Schrage 1982: 226 en Ridderbos 1959: 288 vir kritiek op hierdie standpunt).

Met hierdie histories beperkende opvattings hang in 'n sekere sin ook die gedagte saam dat Paulus in die lig van die Naherwartung wel positief oor die owerheid kon dink en skryf (Dibelius 1956: 184). Daar is hiervolgens dus ' $n$ eskatologiese voorbehoud aan die oproep verbonde. Daar bestaan geen tyd meer om die bestaande verhoudings te hervorm nie en daarom moet elkeen in sy huidige posisie bly, en dit geld ook met betrekking tot die gelowige se onderworpenheid aan die staat wat slegs iets voorlopigs en verbygaande is. Hiervolgens moet die perikoop gesien word binne die omraming van 12:1, 2 en 13:11-14 wat 'n eskatologiese voorbehoud stel. 'Auch der Staat ist ein Provisorium, das der vergehenden Welt angehört, nichts Letztes und Absolutes, sondern etwas Vorletztes und Vorläufiges' (Schrage 1982: 227; kyk ook Cullmann 1961: 43).

Dit is duidelik dat konsensus oor hierdie saak moeilik, indien ooit, bereik sal kan word. In die teks self is daar geen aanduiding van 'n moontlike konkrete situasie wat as aanleiding daartoe gedien het nie (so tereg Neugebauer 1962: 166). Die voorgestelde hipoteses wek die indruk van ' $n$ afskaling van die radikaliteit van die uitsprake in die perikoop. Dit lyk na pogings om daarby verby te kom. Hieroor later meer.

\subsection{Waarna verwys exousíai?}

Daar is ook nog 'n ander hoek van waaruit hierdie perikoop bekyk is, naamlik vanuit die sogenaamde angelologiese verklaring van die meer- 
voud exousiai ( $v 1$ ). Hierdie opvatting waarvan die bekendste en ywerigste eksponent Cullmann (1961: $40 \mathrm{vv}$ ) was, behels dat exousía geïnterpreteer moet word as nie slegs verwysend na die aardse owerheid nie, maar ook en veral na die engelmagte wat agter die aardse owerhede staan en wat deur Christus oorwin en versoen is. Aan hierdie magte kan die Christen hom gewillig onderwerp omdat hulle reeds deur Christus oorwin is. Die staat is nie goddelik nie, maar slegs Godgewil solank hierdie aiōn nog voortduur. Hy tree slegs as dienaar van God op wat die regte oordeel oor goed en kwaad vel, en daarom moet 'n mens jou aan hom onderwerp. Wat Paulus hier van die gelowiges vereis, is eintlik niks meer as wat Jesus volgens Markus 12:13 as riglyn neergelê het nie. Dit hou egter ook die negatiewe implikasie in: 'Gebet ihnen nicht, was ihr ihnen nicht schuldet' (Cullmann 1961: 43). Paulus verwag nie van sy lesers 'einer bedingungs- und kritiklosen Unterwerfung unter jede staatliche Forderung' nie (Cullmann 1961: 42). Die staat moet alleen gehoorsaam word solank hy as dienaar van God binne sy grense bly. Word hy totalitêr, dan eis hy vir homself op wat God toekom, en is die gelowige nie meer aan hom gehoorsaamheid verskuldig nie.

Hierdie angelologiese interpretasie verskil duidelik nie veel van die hierbo genoemde eensydig eskatologiese benadering waarvolgens die owerheid gesien word as ' $n$ instelling wat nog net vir ' $n$ klein rukkie sal bestaan nie. Dit is dus slegs ' $n$ Christologiese variasie van dieselfde gedagte en dit het tot dusver min steun gekry. Die oorgrote meerderheid eksegete het dit op goeie filologiese en teologiese gronde oortuigend afgewys. Daar is in die perikoop eenvoudig geen aanduiding dat Paulus naas die empiriese aardse owerheid, ook nog metafisiese magte in gedagte het nie. En behalwe dat met pâsa exousia (enkelvoudige meervoud) in 1 Korintiërs 15:24 meer as een (metafisiese) mag veronderstel word, wie se onderwerping buitendien eers by die paroesie sal geskied, is daar in die egte Paulusbriewe geen aanduiding van die gebruik van die meervoud exousíai met verwysing na engele of demone magte nie. Cullmann moet uit nie-Pauliniese literatuur soos Efesiërs en Kolossense bewyse gaan haal om sy argument te probeer staaf. In hierdie gevalle is die kontekste ook totaal anders en onvergelykbaar. Die enigste vergelykbare nie-Pauliniese parallel is Titus $3: 1$, en in hierdie geval is dit uit die konteks meer as duidelik dat aardse magte bedoel word (kyk vir 'n grondige en uitvoerige weerlegging van hierdie benadering onder andere by Neugebauer 1962: 168 vv; Käsemann 1974: 337 v; Riekkinen 1980: $166 \mathrm{vv}$; Wilckens 1982: 32). 


\subsection{Impliseer hupotássesthai onvoorwaardelike onderworpenheid of gehoorsaamheid?}

'No contemporary exegete accepts Paul's call to obedience as being unconditional except those who might argue that the text is non-Pauline' (Reese 1973: 330). By 'n oorsig oor die hedendaagse eksegese blyk dit dat Reese dit volkome reg het met hierdie stelling. Maar dan moet daarby gesê word dat dit by verskillende eksegete uit verskillende oorwegings geskied en dat dit beslis nie gedoen kan word deur die werkwoord hupotássesthai semanties af te skaal nie (so tereg Reese 1973: 330). In hierdie verband is die volgende stelling van Wilckens volledig te onderskryf: 'Paulus mahnt zum Gehorsam generell und ohne Einschränkung oder Ausnahme' (Wilckens 1982: 40).

Soos reeds opgemerk, is dit egter duidelik dat daar in die geskiedenis van die eksegese, en veral in resente tye, in mindere of meerdere mate ' $n$ ongemak ondervind is met die radikale eis tot onderworpenheid wat deur hierdie perikoop gestel word. Daarom dat daar op allerlei wyses gepoog is en word om die eis tot gehoorsaamheid te relativeer. Of so iets aan die teks laat reg geskied en in watter mate gerelativeer mag word, indien toelaatbaar, sal ons nog moet uitmaak.

\section{WAT SÊ DIE TEKS?}

\subsection{Voorafopmerkings}

By 'n uiteindelike eksegese van hierdie perikoop sal dit onvermydelik wees om uitsluitsel te moet probeer kry oor die belangrikste eksegetiese vraagstukke wat daar onderliggend aan die teks is en waarmee tradisioneel geworstel is. Hierbo is egter in die meeste gevalle reeds bepaalde standpunte ingeneem en die bedoeling is nie om weer breedvoerig daarop in te gaan of om onnodig te herhaal nie.

Wat die samehang van die perikoop met sy paranetiese konteks betref, moet erken word dat dit inderdaad 'n selfstandige, afgeronde geheel vorm. Dit staan nie in 'n direkte verband met die konteks nie en daar kan hoogstens gesê word dat dit deel vorm van die paranetiese blok van die Romeinebrief. As sodanig is dit dus as imperatief gegrond op die indikatief van die Christusgebeure en die gelowige toeëiening daarvan deur die gelowige. Uit die konteks is daar derhalwe nie veel, indien enige, wat by die eksegese van hulp kan wees nie. 
Dat 'n Christologiese begronding van die argumentasie in die perikoop self ontbreek, kan nie ontken word nie. Dit moet waarskynlik toegeskryf word aan die feit dat ons hier tot op groot hoogte te doen het met tradisionele paranese wat Paulus, of die gemeente voor hom, uit die Umwelt oorgeneem het, wat die herkoms daarvan ook al presies was. Dit hoef egter, soos reeds gesê, geen afbreuk te doen aan die erns van die saak wat hier aan die orde is nie. Indien dit wel as relativerend beskou sou moes word, kan dieselfde immers van bykans alle NuweTestamentiese etiek gesê word, aangesien daar, soos bekend, min etiese uitsprake in die Nuwe Testament voorkom wat nie van elders oorgeneem is en van 'n nuwe konteks voorsien is nie. Maar dan mag ook nie vergeet word nie, dat die vroegste Christene reeds in die $\mathrm{Ou}$ Testament verskeie voorbeelde tot hulle beskikking gehad het waarin uitsprake gemaak word met tot op groot hoogte dieselfde motiewe as wat in hierdie perikoop voorkom (kyk bv Spr 8:15 v; 21:1; 24:21; Jes 41:2 vv; 45:1 vv; Jer 25:9; 27:6; 43:10; Dan 2:21, 37; 5:21 en vgl Friedrich et al 1976: $145 \mathrm{v}$ ). Bloot die feit dat Paulus hom in die lig van die Christusgebeure met ' $n$ bepaalde motief of motiewe vereenselwig, moet as deurslaggewend vir sy argumentasie beskou word. En soos ons reeds hierbo gesien het, is daar geen afdoende rede om die perikoop as niePaulinies uit te suiwer nie.

\subsection{Struktuur en strekking}

Gaan kyk ons nou na die struktuur van die perikoop waarvolgens die argument daarin gevoer word, blyk dit dat dit uiteenval in drie groeperings, te wete verse $1-2 ; 3-5$ en 6-7 (kyk Louw 1979a: 32; 1979b: 123 v). Die gang van die argument kan dan soos volg uiteengesit word:

\subsubsection{Verse 1-2}

Die skopus van die perikoop lê in die basiese oproep in vers 1: elke mens moet hom onderwerp aan die owerhede wat oor hom gestel is. Hierdie oproep word vervolgens prinsipieel begrond in die res van vers 1 : ' $n$ mens moet jou onderwerp omdat die owerhede daar is deur die beskikking van God, dus God-gewil is. Vers 2 trek op grond van hierdie prinsipiële begrondig op sy beurt weer die tweeledige konsekwensie, naamlik prinsipieel en prakties, in die geval van verset teen die owerheid. Die prinsipiële konsekwensie is dat ' $n$ mens dan in opstand kom teen die ordening van God, en die praktiese is dat jy daarvoor jou verdiende straf sal kry. 


\subsubsection{Verse 3-5}

In hierdie groepering word 'n verdere begronding van die oproep in vers 1 aangevoer. Dit word gedoen in verse $3-4$ waarin basies gesê word dat die owerheid as dienaar van God daar is om die kwaad te bestry, en dus tot jou beswil daar is, terwyl in vers 5 saamgevat word wat onderskeidelik in verse 1-2 en 3-4 gesê word. Die slotsom hier (in vers 5 ) is dat ' $n$ mens jou aan die owerheid moet onderwerp, nie net omdat jy vir straf bang is nie, maar ook omdat dit 'n gewetensaak is.

\subsubsection{Verse 6-7}

Hier word ' $n$ derde begronding vir die oproep in vers 1 aangevoer, en dit uit die alledaagse praktyk van die betaal van belastings. Met die betaal van belastings word in feite die gesag van die owerheid erken, en dit doen almal, al was dit deur al die eeue heen by belastingbetalers 'n ongewilde en dikwels gehate verpligting. Die perikoop word dan afgesluit met die vierledige oproep om aan die owerheidspersone te gee wat aan hulle toekom.

\subsection{Die basiese aanspraak van die teks}

Vir ons doel is dit nie nodig om eksegeties op besonderhede in die perikoop in te gaan nie. Dit is slegs nodig om te vra na die aard en die gewig van die basiese aanspraak van die perikoop en na die toepasbaarheid daarvan in die hedendaagse situasie. Om mee te begin, daar is eenstemmigheid by baie eksegete dat ons nie hier met ' $n$ teologiesmetafisiese of natuurregtelike begronding van die staat te doen het nie. Staatsfilosofie of staatsteorie is dus nie hier ter sprake nie, en wat hier van die owerheid gesê word, kan derhalwe deur geen owerheid as skeppingsordening voorgehou word nie (kyk onder andere Käsemann 1974: 338; Wilckens 1982: 34; Bornkamm 1969: 217; Schlier 1979: 388; Conzelmann 1968: 245). 'Rather than affirming a "Christological foundation of the state", Paul calls for a "Christological foundation of citizenship", which is addressed to the individual Christian' (Hultgren 1976: 267). Die owerheid word nie hier aangespreek nie, maar wel die gelowiges, en tog ook weer op so 'n wyse dat die eis om onderworpenheid nie net die gelowiges geld nie, maar streng gesproke 'elke mens'. 'Nirgendwo anders gibt es bei Paulus sonst eine Paränese, in der ein Unterschied zwischen Christen und Nichtchristen faktisch als so schlechterdings inexistent gilte, wie es die Sprache in 13,1-7 nahelegt' (Wilckens 1982: 39). 
Die onderworpenheid wat hier geëis word, is inderdaad radikaal en dit word op uiters stellige wyse gedoen, en, soos ons gesien het, prinsipieel met 'n ordening van God begrond. Die werkwoord hupotássesthai wat hier gebruik word, druk ook sterker as hupakoúein die gedagte uit van ' $n$ daargestelde orde waarvan die minagting tot die versteuring van die lewe van die gemeenskap lei (so tereg bv Käsemann 1974: 336; Schlier 1979: 387). Die eis word ook nie gestel met die veronderstelling dat dit nie meer sal geld indien die owerheid nie sy verpligtings nakom nie (teen Reese 1973: 330). Die eis word deur Paulus gestel wel bewus van die feit dat die Romeinse owerheid heidens is en hom aan baie ergerlikhede skuldig maak. En was die kruis van Christus nie vir hom dié voorbeeld hiervan nie (vgl Wilckens 1982: 35; Käsemann 1974: 340)? Hy weerhou hom egter van 'n evaluering van die bestaande owerheid. Hy skets slegs wat die funksie van die owerheid is en wat die houding van die onderdaan teenoor die owerheid moet wees. Ons hoor hier dus niks van die goed- of afkeuring van die empiriese Romeinse staatsbestel nie. Dit gaan immers om 'n prinsipiële saak, ongeag hoe die bepaalde staatsbestel daar uitsien.

Dit is ook foutief om die radikaliteit van die eis tot onderworpenheid teen ' $n$ historiese of eskatologiese agtergrond te probeer afwater. Ons het reeds gesien dat die pogings om vir die perikoop ' $n$ aanleiding en verklaring te vind in een of ander konkrete politieke situasie, hoogs spekulatief is. Dit is nie uit die perikoop self af te lei nie, en die res van die Romeinebrief gee ook geen blyke daarvan nie (vgl Wilckens 1982: 34). Dit is wat die eskatologiese aspek betref, waar dat Paulus in 13:11-14'n redelike sterk Naherwartung huldig, maar in die perikoop self dui niks daarop dat die eise wat dit stel, van hieruit as getemper beskou moet word of as slegs bedoel vir 'n kort periode voor die paroesie nie. Wilckens merk in hierdie verband heeltemal tereg op: 'Man kann ... nicht sagen, das Gewicht der Aussagen über den Staat sei durch den eschatologischen Horizont eingeschränkt oder relativiert' (Wilckens 1982: 40). Inteendeel, ' $\ldots$ der Duktus des Textes schliesst eine solche sogar aus' (Wilckens 1982: 40). Die owerheid vervul selfs 'n bepaalde funksie met betrekking tot die oordeel wat kom (orgé, vs 4). Sonder om dus te beweer dat wat hier geëis word, onbeperk vir alle tye en omstandighede geld, kan ook nie afgelei word dat dit die intensie van die teks was dat dit slegs vir 'n beperkte tyd moes geld nie. So 'n terminering is eenvoudig nie in die gesigsveld van die teks nie. Dit is wel waar dat Paulus in die lig van die nabye verwagting van die paroesie, die aardse bedeling en aardse instellings as van verbygaande 
aard en as tydsbegrens gesien het (vgl 1 Kor 7:29 vv). Dit is ook waar dat hy die gelowige se ware burgerskap as 'n hemelse beskou het (Fil 3:20) en die gelowige gesien het as gerig op die onsigbare, ewige dinge en nie op die sigbare, tydelike nie ( 2 Kor 4:18). Dit is egter nie genoeg rede om te veronderstel dat hy die gelowige se burgerlike verantwoordelikheid in die konkrete alledaagse werklikheid daarom ligtelik opgeneem het nie. Ons teks getuig van die teendeel.

Waarop verder gewys moet word, is dat die prinsipiële begronding van die eis tot onderworpenheid in vers 1 , in vers 5 gerugsteun word deur 'n beroep op die gewete. Waarop dui suneídēsis hier? Verskillende verklarings is hiervoor gegee, maar in die konteks kan dit kwalik anders as in samehang met die prinsipiële stelling in vers 1 gelees word. Dit lyk nie voldoende om dit te interpreteer as bloot verwysend na die vermoë om tussen goed en kwaad te onderskei of in 'n politieke situasie die regte besluit te neem nie. Vir die Christen moet dit minstens dui op sy gewete voor God, op sy Christelike gewete waardeur hy ooreenkomstig 12:2 onderskei wat die wil van God is, en dienooreenkomstig handel (so tereg Friedrich et al 1976: 164; kyk ook Ridderbos 1959: 293). Maar in die lig daarvan dat die perikoop so 'n algemene strekking het en in die lig van wat in 2:15 oor die gewete van die heidene gesê is, word suneidésis hier waarskynlik ook in ruimer sin as net die Christelike kader bedoel (vgl Wilckens 1982: 37). Wat egter belangrik is, is dat die motivering vir onderworpendheid hierdeur tot 'n positiewe gemaak word. Daar is wel ook die negatiewe motivering van vrees vir straf, en dit is 'n effektiewe motivering. Tog moet dit nie die primêre motivering wees nie, inteendeel die werklike motivering moet wees dat onderworpenheid aan die owerheid ' $n$ gewetensaak is. Dit gaan om wat hoort, om wat vir God goed, en aanneemlik en volmaak is.

\section{ROMEINE 13 IN DIE HUIDIGE SITUASIE}

En tog, ondanks alles wat tot hiertoe gesê is, is daar eenstemmigheid by eksegete dat Romeine 13:1-7 nie sonder meer en ongekwalifiseerd op latere situasies en so ook in ons situasie van toẹpassing gemaak kan word nie. So algemeen en absoluut as wat die eis om onderworpenheid in die perikoop deur baie beskou word, so tydsgebonde en begrens word dit tog ook beskou wanneer dit kom by die vraag na die relevansie daarvan vir ons situasie. Ons probleem is natuurlik dat die teks hom hoegenaamd nie uitlaat oor moontlike omstandighede waaronder weerstand teen die owerheid geregverdig sou kon word nie. Om by die 
probleem te probeer verbykom, soos so baie in moderne tye gebeur, deur ' $n$ onderskeid te maak tussen hulle wat de facto regeer aan die een, en gesag as 'n God-gegewe prinsipe aan die ander kant, laat ook nie reg aan die teks geskied nie. Die teks maak eenvoudig nie onderskeid tussen gesag as 'n prinsipe wat daar is vir die beswil van die publiek en waaraan ' $n$ mens jou ten alle tye moet onderwerp, en die persoon wat die gesag uitoefen en wat na goeddunke uitgegooi kan word nie (so tereg Hultgren 1976: 267).

Wat natuurlik altyd onthou moet word, is dat eksegese wat, soos dit hoort, afgestem is op die situasie en konteks waarin die eksegese plaasvind, nooit slegs die oorspronklike situasie van die teks in berekening mag bring en daarby mag stilstaan nie. Alle eksegese moet altyd beide kontekste laat meespreek, dié van die teks en dié van die eksegeet of leser.

Wat die moderne situasie betref, minstens in die wêreld van Westerse demokrasieë, is die saak grondig anders as dié waarin die teks ontstaan het (vgl Wilckens 1982: $41 \mathrm{vv}$ ). In die eerste plek is dit in die moderne demokratiese staat prinsipieel nie meer so dat die owerheid en die onderdane in ' $n$ teenoorgestelde verhouding tot mekaar staan nie. Daar is die deur-die-volk-verkose wetgewende en uitvoerende regeringsliggame en daar is die onafhanklike regsprekende instelling. Die regspraak en strafproses is ook nie primêr ingestel op eliminering uit die gemeenskap nie, maar op rehabilitasie. Die regeerders is dus nie tegelyk die regters nie en al hierdie liggame is uiteindelik aan die volk of die stemgeregtigdes verantwoording verskuldig. Hoewel die moderne owerheid homself ook in die oorgrote meerderheid van gevalle nie meer as ' $n$ dienaar van God sien nie, maar as ' $n$ sekulêre instelling, is daar in werklikheid in so 'n demokratiese bedeling inderdaad oneindig meer moontlikhede vir die staat om die goeie te bevorder, as wat in Paulus se tyd die geval was. Opposisiepartye het ook die geleentheid om vryelik aan verkiesings deel te neem en om in die bestel deur debat en andersins hulle invloed op beleid en besluitneming uit te oefen. Maar dit geskied altyd met die demokratiese veronderstelling dat die minderheid hom aan die meerderheid sal onderwerp.

In so ' $n$ demokratiese bedeling is daar verder ook bykans onbeperkte geleenthede vir die burgers om op verskillende vlakke en deur middel van talle liggame en organisasies inspraak te hê, beheer uit te oefen en 'n bydrae te maak tot ' $n$ geordende, regverdige en nuttige bestel vir al die burgers. Kritiek op die handelinge van die owerheid word nie 
alleen as ' $n$ reg nie, maar ook as 'n plig beskou. En medeverantwoordelikheid is 'n aanvaarde beginsel, sodat die skuld vir' $n$ swak regering of staatsbestel, tot op groot hoogte voor die deur van die burgers gelê kan word. Medeverantwoordelikheid sluit ook die materiële in en daarom word die betaal van belastings in ' $n$ ander lig as vroeër gesien. Dit is die bydrae van die burgers vir die gemeenskaplike belang waarvoor almal 'n verantwoordelikheid voel.

Die moderne inligtingsbronne en die media, hoe bedenklik dikwels ook al, lewer ' $n$ belangrike bydrae tot 'n oop, vrye en regverdige samelewing. As gevolg van die beskikbaarheid en rol van moderne kommunikasiemiddels leef geen gemeenskap in die Weste ook meer in isolasie nie, maar as deel van 'n groter gemeenskap. Dit het onvermydelik 'n uitwerking op die wyse waarop so 'n gemeenskap homself organiseer en regeer.

Die prentjie wat hierbo van 'n Westerse demokrasie geskilder is, kom natuurlik baie idealisties voor. Almal weet egter dat ' $n$ ideale staatsbestel en ' $n$ ideale samelewing nie bestaan nie. Daarom sal pogings voortgaan om 'n steeds idealer bestel tot stand te bring. Dikwels is verandering ook nie ' $n$ verbetering nie. Dit het almal ook al ervaar. Maar wat wel gesê kan word, is dat daar binne 'n moderne demokratiese bestel geen rede behoort te wees vir ongehoorsaamheid aan of verset teen die owerheid nie, en allermins gewapende verset. Daar is eenvoudig meer as voldoende wyses waarop en kanale waarlangs verandering teweeggebring kan word.

Maar die moeilikste vraag bly oor. Wat kan en mag die burger, en dan veral ook die gelowige burger, doen as hy nie binne so ' $n$ bestel leef nie en daar dus nie vir hom demokratiese weë oop is nie? In ons perikoop word gestel dat die funksie van die owerheid basies dié is van die daarstelling en handhawing van die goeie orde deur nie alleen tussen goed en kwaad te onderskei nie, maar ook eersgenoemde te prys en laasgenoemde te straf. Dat (goeie) orde selfs deur tiranne gehandhaaf is, is dikwels toegegee. Met ander woorde dit is ' $n$ vraag of daar 'n owerheid kan wees wat hoegenaamd geen orde handhaaf en daarom geen lewensruimte moontlik maak nie.

Die minste wat in elk geval seker van elke burger verwag kan word, is om nie deur sy optrede die bestaande orde te versteur, as hy nie werklik ' $n$ beter een in die plek daarvan kan stel nie. Dit is in hierdie opsig dat elke burger, en die burgery in die algemeen, voor ' $n$ groot verantwoordelikheid geplaas word. Vir sover Romeine 13 ter sprake gebring kan word in ' $n$ bepaalde situasie, sal dit sonder twyfel die eis 
moet stel dat die verandering wat beoog word, nie die vervanging van een sogenaamde euwel slegs deur 'n ander en miskien groter euwel mag wees nie. Maar wat moet hier die maatstaf wees?

Vir die Christen en die kerk kan daar natuurlik nie ' $n$ ander maatstaf wees as die Bybel nie. Maar ons is ons volkome daarvan bewus dat Christene en kerke dieselfde teks dikwels verskillend interpreteer. Dit geld juis nou ook Romeine 13 (vgl The kairos document [1985]: $3 \mathrm{vv}$ ). Maar selfs al sou hierdie teks in moderne tye nie meer so letterlik geneem kan word soos hy daar staan nie, staan sy basiese eis nog onverswak daar. Sy basiese eis kan ook geformuleer word as die eis om die verantwoordelikheid en keuse vir orde, en om die bestryding van chaos en anargie. Hoe hierdie orde bevorder en gehandhaaf moet word, is telkens in elke nuwe situasie die gesamentlike verantwoordelikheid van al die burgers en nie die van 'n groepie eensydige en anargistiese revolusionêre nie.

In revolusionêre optrede is dit sonder uitsondering so dat geïsoleerde en dikwels opgeblaasde griewe ten koste van gemeenskaplike belange uitgebuit word. Soos bekend, gaan dit in so 'n optrede dikwels ook uitsluitlik om die vestiging van die ideologie van ' $n$ handjievol fanatici eerder as om die belange van die gemeenskap. En net so dikwels word orde inderdaad met chaos en euwel vervang. Vanweë hierdie gevaar kan 'n mens jou nie 'n samelewing sonder die basiese eis van Romeine 13 voorstel nie. Hierdie basiese eis was en is soos ons reeds gesien het, nie uitsluitlik Christelik nie. Sy alternatief is egter in enige samelewing ondenkbaar. Sy alternatief, van watter aard ook al, sal neerkom op die uitlokking en aanmoediging tot revolusie, soos dit trouens ook telkens gebeur waar daarvan afgesien word. Dat die intensie van Romeine 13 in elke samelewing onverswak gehandhaaf moet bly, impliseer egter nie 'n kritieklose en slaafse onderworpenheid aan 'n staatsbestel nie. Die wêreld behoort daarby lank reeds verby te wees. Ons moet egter toegee dat 'n enkelvoudige antwoord nie moontlik is nie. In elke nuwe situasie sal steeds nuut en met die grootste nugterheid en verantwoordelikheid opgetree moet word.

Hiervoor is Romeine 13 as direktief uiters noodsaaklik. Hy moet streng gesproke as struikelblok in die pad bly lê, nie as koue, uitgediende dogma nie, maar as waarborg dat indien daar vir fisiese of gewelddadige optrede teen die owerheid gekies word, dit werklik die laaste en enigste uitweg sal wees. Dit moet dus altyd die kritiese vraagteken bly wat oor alle optrede hang. Dit moet onvermydelik die gevolg hê dat alle optredes vir dié wat enigsins 'n gewete het, 'n 
gewetensaak sal wees. Dit is trouens wat Romeine 13 in werklikheid van elke burger vra: laat jou optrede onder alle omstandighede deur jou gewete gelei word. By die Christen sal dit natuurlik nie iets anders wees as sy gewete voor God nie. En van gewete voor God kan daar immers nie sprake wees, anders as dat dit deur die Woord van God gevorm is nie.

Intussen moet die eis aan elke burger of burgerlike groepering, of hy nou Christelik is of nie, onverswak gestel word dat hy ten alle tye sy bydrae tot 'n ordelike en vooruitstrewende samelewingsverband moet lewer. Dit kan gebeur as hy juis deur sy optrede 'n bestel help tot stand bring waarin rede tot ontevredenheid of opstand tot die minimum beperk is, of glad nie sal bestaan nie. Die aard en kwaliteit van die owerheid, en so ook van die samelewing, behoort noodwendig te korreleer met die insette wat die burgery lewer.

Elkeen wat enigsins fisiese optrede oorweeg, sal lank voordat hy dit doen hom eers moet afvra watter inset hyself gelewer het om die toestand waarteen hy in opstand is, te kon verhoed het. Waar die burgery sy taak so sien, sal burgery en staat nie hulle rol as twee teenoormekaarstaandes vervul nie, maar as medeverantwoordelikes. Ten slotte, die Christelike kerk, en so die gelowiges, kan nie anders as om die intensie van Romeine 13 te handhaaf nie, nie ongekwalifiseerd nie, maar altyd met al die insig, wysheid en goeie oordeel waaroor die kerk op elke stadium mag beskik vir die toepasbaarheid daarvan in die situasie van die dag. Op die keper beskou, gaan dit hier om 'n dialektiese proses, maar so dat enersyds die situasie nie die verstaan van die teks eensydig voorskryf nie en andersyds die teks hom nie dogmaties op die situasie afdwing nie. In hierdie dialektiese hermeneutiese proses waarin die teks en sy intensie altyd die voorrang het, behoort, indien die proses reg verloop, die intensie van die teks in die nuwe situasie nuwe verstaanshorisonne te open en nuwe bestaansmoontlikhede te skep.

Hierdie poging om Romeine 13:1-7 vanuit 'n hedendaagse perspektief te verstaan, word aangebied ter ere van 'n hooggewaardeerde leermeester, vriend en kollega. Dit word veral gedoen in die wete dat vir PS Dreyer die belange van beide die ekklesía en die politeía nog altyd na aan die hart gelê het en 'n gewetensaak was. 


\section{Literatuuraanwysings}

ALTHAUS, P 1970. Der Brief an die Römer. 11. Aufl. Göttingen: Vandenhoeck. (NTD 6.)

BARRETT, CK 1977. The epistle to the Romans. London: A \& C Black. (BNTC.)

BORG, M 1973. A new context for Romans XIII. NTS 19, 205-218.

BORNKAMM, G 1969. Paulus. 2. Aufl. Stuttgart: Kohlhammer. (UB 119.)

CONZELMANN, H 1968. Grundriss der Theologie des Neuen Testaments. 2. Aufl. München: Kaiser.

CONZELMANN, H \& LINDEMANN, A 1970. Arbeitsbuch zum Neuen Testament. 5. Aufl. Tübingen: Mohr. (UTB 52.)

CULLMAN, O 1961. Der Staat im Neuen Testament. 2. Aufl. Tübingen: Mohr.

DIBELIUS, M 1956. Rom und die Christen im ersten Jahrhundert, in Botschaft und Geschichte. 2. Bd, 177-228. Hrsg von G Bornkamm. Tübingen: Mohr.

FRIEDRICH, J, POHLMANN, W \& STUHLMACHER, P 1976. Zur historischen Situation und Intention von Röm 13, 1-7. ZThK 73, 131-166.

HULTGREN, A] 1976. Reflections on Romans 13:1-7: Submission to governing authorities. Dialog 15, 263-269.

KÄSEMANN, E 1974. An die Römer. 2. Aufl. Tübingen: Mohr. (HNT.)

KUSS, O 1963. Paulus über die staatliche Gewalt, in Auslegung und Verkündigung I: Aufsätze zur Exegese des Neuen Testaments, 246-259. Regensburg: Pustet.

LOUW, JP 1979a. A semantic discourse analysis of Romans, Vol I: Greek text. Pretoria: University of Pretoria.

LOUW, JP 1979b. A semantic discourse analysis of Romans, Vol II: Commentary. Pretoria: University of Pretoria.

MICHEL, O 1963. Der Brief an die Römer. 12. Aufl. Göttingen: Vandenhoeck. (KEK.)

NEUGEBAUER, F 1962. Zur Auslegung von Röm 13, 1-7. KuD \&, 151-172.

NYGREN, A 1965. Der Römerbrief. 4. Aufl. Göttingen: Vandenhoeck.

PARROTT, RL 1980. Paul's political thought: Rom 13:1-7 in the light of Hellenistic political thought. Michigan: Ann Arbor. (UMI.)

REESE, T] 1973. Pauline politics: Rom 13:1-7. BTB 3, 323-3,31.

RIDDERBOS, HN 1959. Aan de Romeinen. Kampen: Kok. (CNT (K).)

RIEKKINEN, V 1980. Römer 13: Aufzeichnung und Weiterführung der exegetischen Diskussion. Helsinki: Suomalainen Tiedeakatemia. AASF. (Dissertationes humanarum litterarum 23.)

RUNIA, K 1986 . Romeinen 13 vandaag: Bidden voor de val van de regering Botha?

SCHLIER, H 1958. Die Beurteilung des Staates im Neuen Testament, in Die Zeit der Kirche: Exegetische Aufsätze und Vortrage. 2. Aufl, 1-16. Freiburg: Herder.

SCHLIER, H 1979. Der Romerbrief. 2. Aufl. Freiburg: Herder. (HThK.)

SCHMITHALS, W 1975. Der Römerbrief als historisches Problem. Gütersloh: Gerd Mohn. (StNT 9.)

SCHRAGE, W 1982. Ethik des Neuen Testaments. Göttingen: Vandenhoeck. (GNT 4.)

THE KAIROS DOCUMENT. CHALLENGE TO THE CHURCH: A THEOLOGICAL COMMENT ON THE POLITICAL CRISIS IN SOUTH AFRICA. [1985]. The Kairos Theologians: Springs Advertiser.

WENDLAND, H-D 1970. Ethik des Neuen Testaments: Eine Einführung. Göttingen: Vandenhoeck. (GNT 4.)

WILCKENS, U 1982. Der Brief an die Romer. 3. Teilbd Zürich: Benziger. (EKK.) 